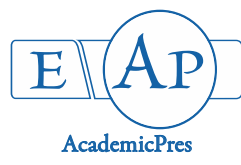

\title{
The Effect of Soil Mediated Genetic Changes and Plasmid Curing on Growth Rates of Pseudomonas and Staphylococcus spp. Isolated from Different Soils
}

\author{
Onyemaechi Henry OBIAZIKWOR*, Ebiye Kevwe OGAH, \\ Hakeem Olalekan SHITTU
}

University of Benin, Faculty of Life Sciences, Department of Plant Biology and Biotechnology, Benin City, Nigeria; onyemaechi.obiazikwor@uniben.edu (*corresponding author)

\begin{abstract}
The study was carried out to investigate the effect of soil mediated genetic change on growth rate of bacterial isolates from soils collected from different environments. Soil samples were collected from different sites: cow dung contaminated area, poultry, mechanic workshop, river, farmland and garden soils. Physiochemical analysis, bacteria isolation and enumeration were carried out on the different soil samples. Growth rate was determined by the measurement of turbidity at $600 \mathrm{~nm}$ using UV/VIS spectrophotometer on all isolates from two selected species (Pseudomonas and Staphylococcus) because of their even distribution in the soil samples. Plasmid curing was carried out on the selected isolates using $1 \mathrm{ml}$ of $10 \%$ Sodium Dodecyl Sulphate as the curing agent and the growth rate of the plasmid-cured isolates were investigated. The results obtained indicated that the soil samples varied in their physiochemical properties. There were differences in the growth rates of bacterial isolates from the different soils for both Pseudomonas and Staphylococcus spp. a comparison between growth rate of test bacteria isolates before and after plasmid curing also suggested that curing significantly affected the growth rate of the test organisms in some soil samples. The results from this study suggested that the soil environments from which the various bacterial isolates were obtained had effect on the genetics of the bacteria isolates. The future direction to this study is to perform a molecular profiling of the various isolates to determine species specificity and also test for their virulence.
\end{abstract}

Keywords: DNA isolation; pathogen evolution; plasmid; phytopathogen; virulence

\section{Introduction}

Soil is a multi-layered surface complex of mineral and organic (humus) constituents present in solid, liquid, and gaseous states, thus making it a very rich place for inhabitation by microorganisms. The quantity and type of microorganisms in a particular portion of soil are determined by a complex interaction of varying amounts of sunlight, temperature, moisture, soil $\mathrm{pH}$, nutrients, and redox potential (Agrios, 2005). These microorganisms could be pathogenic or non-pathogenic. Pathogens may be indigenous or enter the soil through deliberate introduction (for purposes of biological control) or indirectly by animal deposits, manure application, or from flooding with sewage or contaminated water. Soil-inhabiting bacterial pathogens are exposed to various physical, biological and chemical factors in the environment and these factors tend to affect the growth and proliferation of these pathogens. The ability to grow and proliferate fast in the host by a pathogen can also be attributed to its virulence (Agrios, 2005). Bacterial organisms, unlike eukaryotes possess one chromosome that houses the genetic material. In addition to the chromosomal DNA, these organisms also possess an extrachromosomal DNA known as plasmid (Weaver, 2012). Plasmids in most times do not carry essential genes for the growth of host cells under non stressed conditions (Carattoli, 2011) but, under certain conditions, may confer a selective benefit. This might include enzymes for utilization of unusual carbon sources (Zhang et al., 2011), resistance to antimicrobials such as heavy metals, antibiotics (Bennett, 2008) and production of toxins and other proteins that allow the successful infection of the bacterial cell (Sengupta and Austin 2011). Therefore, the presence and absence of plasmid has the potential of affecting the growth rate of a bacterial pathogen, which may inadvertently affect the virulence of the pathogen. The soil environment in which an organism is domicile could affect the genetic make -up of the organism. It is therefore expedient to investigate the effect of soil environment on the growth rate of the test pathogens in order to recommend possible prevention and 
402

control measures. The aim of the current study was to investigate the effect of soil mediated genetic change on the growth rate of Staphylococcus and Pseudomonas spp. isolated from different soils.

\section{Materials and Methods}

\section{Collection of samples}

Soil samples were collected from six different sites in Benin City, Edo state, Nigeria, including cow dung, poultry soil, mechanic workshop, river soil, farmland and garden soil; designated as sample A, B, C, D, E and F, respectively.

\section{Preparation of culture media}

Nutrient agar used for this study was prepared according to manufacturer's instruction. This medium was prepared from commercially available dehydrated powder, available from most suppliers of culture media. In the preparation, 28 $\mathrm{g}$ of nutrient powder was dissolved in 1 litre of distilled water in a conical flask covered with cotton wool and aluminium foil paper. It was mixed thoroughly and sterilized by autoclaving at $121{ }^{\circ} \mathrm{C}$ for 15 minutes. The medium was cooled to $45-50{ }^{\circ} \mathrm{C}$ and then dispensed aseptically into sterile Petri dishes.

\section{Isolation of bacteria organisms}

One (1 g) gram of soil samples from the different soil sample was weighed into sterile beaker and $9 \mathrm{ml}$ of sterilized distilled water was added. The $10^{-1}$ suspension was subsequently serially diluted using fivefold serial dilution up to $10^{-5}$. Aliquot of $0.1 \mathrm{ml}$ of the appropriate dilution from each contaminated soil was plated in nutrient agar for isolation of bacteria. The cultures were incubated at $37^{\circ} \mathrm{C}$ for 24-48 hours. After incubation, the number of discrete colonies was counted in terms of colony forming units. The viable count was obtained from this value by reference to the serial dilution used. Pure cultures of the bacteria isolates were obtained by sub-culturing.

\section{Characterization and identification of bacterial isolates}

Cultural characteristics of the bacterial isolates were observed on Nutrient agar plates and described. The cultural characteristics include size, shape, surface, opacity, texture, elevation; and pigmentation (determined by visual observation). Biochemical tests were also carried out on the bacterial isolates. The tests include gram staining, spore staining, acid-fast stain, motility test, coagulase test, catalase production test, citrate utilization test, methyl red and Voges-Proskauer tests (MR-VP), indole test, oxidase test, urease production test and sugar fermentation test

\section{Growth rate determination of microorganisms}

One loop full of the isolate was introduced into ten (10 $\mathrm{ml}$ ) milliliter of nutrient agar in a test tube. The mixture was standardized with $1.1 \times 10^{5} \mathrm{Mc}$ farland. The turbidity was measured immediately with the UV/VIS Spectrophotometer at $600 \mathrm{~nm}$. The reading was done repeatedly for four days at 24 hour interval.

Plasmid DNA isolation and profiling

Plasmid isolation was carried out using a commercial plasmid isolation kit (ZR Plasmid Miniprep ${ }^{\mathrm{TM}}$ ) according to the manufacturer instructions. About $0.5 \mathrm{ml}$ of the overnight culture was centrifuged. The supernatant was discarded. An aliquot of $200 \mu \mathrm{l}$ of P1 Buffer was added to the pelleted cells. About $200 \mu \mathrm{l}$ of P2 buffer was added and mixed. It was incubated at room temperature for 2 minutes. An aliquot of $400 \mu \mathrm{l}$ of P3 buffer was added and mixed. It was centrifuge at $16.000 \times \mathrm{g}$ for 2 minutes. The supernatant was loaded inside the Zymo-spin ${ }^{\mathrm{TM}}$ IIN column and was centrifuged for 30 seconds. The flow through was discarded. An aliquot of $200 \mu \mathrm{l}$ of Endo- Wash buffer was added to the column in a collection tube and centrifuged for 30 seconds. About $400 \mu \mathrm{l}$ of plasmid buffer was added and centrifuged for 1 minute. The spin column was placed in a new micro centrifuge tube and $30 \mu \mathrm{l}$ of DNA elution buffer was added and centrifuged for 30 seconds (Sambrook and Russell, 2001; Ranjbar et al., 2007).

\section{Preparation of $0.8 \%$ agarose gel}

Zero point eight $(0.8 \%)$ percent agarose gel was prepared by dissolving $0.8 \mathrm{~g}$ in $100 \mathrm{ml}$ Tris EDTA buffer. The mixture was then heated in a microwave for 5 minutes to dissolve completely. It was then allowed to cool at $56^{\circ} \mathrm{C}$ and $6 \mu \mathrm{l}$ of ethidium bromide was added to it. The molten agarose gel was poured into the gel mould with comb, and allowed to solidify.

\section{Plasmid DNA detection}

Ten $\mu$ l of the molecular markers was loaded into the first well. An aliquot of $2 \mu \mathrm{l}$ of the loading dye mixed with $8 \mu \mathrm{l}$ of the plasmid DNA extract was loaded in the other wells. Electrophoresis was performed at $90 \mathrm{v}$ for 60 minutes. After electrophoresis, the products were visualized by Wealth Dolphin Doc UV trans-illuminator and photographed. Molecular weights were calculated using molecular weight standard of the maker.

\section{Plasmid DNA curing}

Procedure as described by Ehiaghe et al. (2013) was used. Nine millilitre of freshly prepared nutrient broth was inoculated with $1 \mathrm{ml}$ overnight culture that was grown in L.B containing antibiotics for 24 hours at $37^{\circ} \mathrm{C}$. The resultant mixture was grown for 4 hours to allow for minimal growth of the microorganisms. An aliquot of $1 \mathrm{ml}$ of $10 \%$ Sodium Dodecyl Sulphate (SDS) curing agent was added to $9 \mathrm{ml}$ nutrient broth culture, and was incubated at $37^{\circ} \mathrm{C}$ for 24 hours. About $1 \mathrm{ml}$ of the cured culture was inoculated unto $9 \mathrm{ml}$ freshly prepared nutrient broth and incubated at $37{ }^{\circ} \mathrm{C}$ for 24 hours. The overnight broth culture was then used to carry out post susceptibility test on Muller Hinton agar plate with the necessary antibiotic disc placed and incubated for 24 hours at $37{ }^{\circ} \mathrm{C}$ for analysis.

Determination of the physiochemical properties of the soil samples

\section{Determination of $p H$}

The $\mathrm{pH}$ reading was obtained with the aid of a Hanna microprocessor $\mathrm{pH}$ multimeter which was earlier standardized with buffer 4.0, 7.0 and 9.0.according to the method described by (Kalra and Maynard, 1991). 


\section{Electrical conductivity}

Twenty (20) grams of the fresh soil sample was weighed into a $100 \mathrm{ml}$ glass beaker. Twenty (20) millilitres of sterile distilled water was added and the suspension was stirred continuously for 30 minutes. The mixture was allowed to stand for another 30 minutes undisturbed. A digital conductivity meter (Labtech) was used in determining soil conductivity by dipping the sensitive rod into the mixture and a steady reading taken.

\section{Moisture content}

The moisture content was determined according to the method described by (Kalra and Maynard, 1991).

\section{Particle size distribution}

Fifty (50) grams of fine textured air-dried soil sample was transferred into a 1 liter dispersion cup. One hundred (100) milliliters of freshly $0.1 \mathrm{M}$ Sodium hydroxide solution was added to the dispersion cup. After thorough mixing, the mixture was placed on a mechanical shaker for 4 hours. The mixture was transferred to a 1 liter measuring cylinder and the volume of the mixture was made up to 1 liter with distilled water. The mixture inside the cylinder was shaken by inversion and the time was noted. After 40 seconds, a hydrometer was inserted into the cylinder and at 5 minutes, the hydrometer scale was read and the temperature of the mixture was also noted. The hydrometer was withdrawn and the process repeated about 3 hours later.

\section{Calculation}

For every $1{ }^{\circ} \mathrm{C}$ above $20^{\circ} \mathrm{C}$, a 0.36 graduation is added to the hydrometer reading and for every $1{ }^{\circ} \mathrm{C}$ below $20^{\circ} \mathrm{C}$, a 0.36 graduation is subtracted. The correct hydrometer readings are obtained by correcting for temperature and subtracting the blank reading (Onyeonwu, 2000).

(a) Silt + Clay $\%=$ corrected hydrometer reading at 40 seconds/ sample weight $(\mathrm{g}) \times 100 \%$

(b) Clay $\%=$ corrected hydrometer reading at 5 hours/sample weight $(\mathrm{g}) \times 100 \%$

(c) Silt $(\%)=(\mathrm{a})-(\mathrm{b})$

(d) Sand $(\%)=100-(\mathrm{a})$

Determination of total nitrogen $(N)$, phosphorus $(P)$, sodium $(\mathrm{Na})$, potassium $(\mathrm{K})$, magnesium $(\mathrm{Mg})$ and calcium (Ca)

The total nitrogen content of the soil samples were determined using micro Kjeldahl digestion and colorimetric method (Bremner and Mulvaney, 1982). The phosphorus, $\mathrm{Na}, \mathrm{K}, \mathrm{Mg}$ and $\mathrm{Ca}$ contents were determined according to the method described by (Onyeonwu, 2000).

Extraction of nitrate, sulphate and ammonium nitrogen from soil

Ten (10) grams of air dried soil was weighed into a plastic bottle. Fifty (50) extraction solution (100 g of sodium acetate, and $30 \mathrm{ml}$ of acetic acid in one liter of distilled water) was added and the mixture was shaken with the aid of a mechanical shaker for 30 minutes. The mixture was filtered using a No 42 Whatman filter paper into a 100 $\mathrm{ml}$ volumetric flask. The filtrate was made up to mark with the distilled water and preserved for nitrate, sulphate, and ammonium nitrogen determination. Nitrate, sulphate and ammonium were determined according to (Onyeonwu, 2000).

\section{Statistical analysis}

Each treatment was in three replicates and results were presented as mean \pm standard error. The data obtained were subjected to parametric (ANOVA and paired t-test) and descriptive statistics using the Statistical Package for the Social Sciences (SPSS), version 20 software. An alpha value of 0.05 was used as the level of significance. Post hoc analysis using the Duncan multiple range test was used to separate the mean when a significant difference was observed.

\section{Results}

The physiochemical analysis of the soil samples (Table 1) showed that the $\mathrm{pH}$ of the analyzed soils were all slightly acidic, with soil samples $B$ and $C$ close to neutral. The ammonium content $(2.56 \pm 0.01)$ of soil sample $C$ was relatively higher than the other soil samples analyzed. The sulphate content $(8.04 \pm 0.02)$ of soil sample D was relatively higher than the other soil samples analyzed. Organic matter (\%) was relatively higher in soil sample C $(5.88 \pm 0.01)$ compared to the other soil samples analyzed. Table 2 showed the heterotrophic bacteria count in the various soil samples. The highest heterotrophic bacteria count was recorded for soil sample $\mathrm{F}\left(7.9 \times 10^{5}\right)$, and this was followed by sample C $\left(7.1 \times 10^{5}\right)$. The lowest heterotrophic bacteria count was recorded for sample D $\left(4.3 \times 10^{5}\right)$.

The growth rate of Staphylococcus and Pseudomonas spp. before curing is shown in Table 3 . There were significant differences recorded in the various days observed $(0-4)$ in the growth rate of Staphylococcus sp. isolated from the different soil samples. There was no significant difference at day 1 in the growth rate of Pseudomonas sp. isolated from soil sample $\mathrm{E}$ and $\mathrm{F}$, but there were significant differences in the other days observed.

Table 4 showed the growth rate of Staphylococcus and Pseudomonas spp. isolated from different soil samples after curing. There was no significant difference between the growth rate of Staphylococcus sp. isolated from sample A and $\mathrm{B}$ after curing at day $0\left(0.199^{\mathrm{bc}} \pm 0.001\right.$ and $0.205^{\mathrm{bc}} \pm 0.005$ respectively). There were significant differences in the growth rate of Staphylococcus sp. isolated from the different soil samples after curing in the other days observed. Significant differences were observed in the growth rate of Pseudomonas sp. isolated from sample $\mathrm{F}$ and $\mathrm{B}$ at day 0 after curing $\left(0.218^{\mathrm{bc}} \pm 0.001\right.$ and $0.197^{\mathrm{bc}} \pm 0.001$ respectively $)$.

The results obtained for the comparison of the growth rate before and after curing showed that there were significant differences $(\mathrm{p}<0.05)$ in the growth rate of Staphylococcus sp. isolated from sample A, B and D, before and after curing, while there was no significant difference ( $p>0.05)$ in the growth rate of Staphylococcus sp. isolated from sample F before and after curing (Table 5). Significant differences $(\mathrm{p}<0.05)$ were observed in the growth rate of Pseudomonas sp. isolated from sample B and $\mathrm{E}$ before and after curing, but there were no significant differences in the growth rate of Pseudomonas sp. isolated from sample $\mathrm{D}$ and $\mathrm{F}$ before and after curing. 
404

Table 1. Physicochemical analysis of experimental soil samples

\begin{tabular}{ccccccc}
\hline \multirow{2}{*}{ Parameter } & \multicolumn{5}{c}{ Soil Samples } \\
\cline { 2 - 7 } & $\mathrm{A}$ & $\mathrm{B}$ & $\mathrm{C}$ & $\mathrm{D}$ & $\mathrm{E}$ & $\mathrm{F}$ \\
\hline $\mathrm{Ph}$ & $5.32 \pm 0.27$ & $6.15 \pm 0.06$ & $6.19 \pm 0.04$ & $5.77 \pm 0.12$ & $5.46 \pm 0.06$ & $5.75 \pm 0.02$ \\
$\mathrm{EC}(\mathrm{uS} / \mathrm{cm})$ & $132.33 \pm 0.33$ & $164.00 \pm 0.58$ & $111.33 \pm 0.33$ & $146.33 \pm 0.88$ & $171.67 \pm 0.88$ & $152.67 \pm 1.20$ \\
$\mathrm{Cl}(\mathrm{mg} / \mathrm{kg})$ & $23.42 \pm 0.22$ & $29.23 \pm 0.24$ & $19.87 \pm .074$ & $26.14 \pm .04$ & $30.90 \pm 0.03$ & $27.60 \pm 0.30$ \\
Sulphate $(\mathrm{mg} / \mathrm{kg})$ & $5.95 \pm 0.03$ & $7.51 \pm 0.03$ & $5.06 \pm 0.02$ & $8.04 \pm 0.02$ & $7.46 \pm 0.16$ & $7.04 \pm 0.01$ \\
Nitrate $(\mathrm{mg} / \mathrm{kg})$ & $10.65 \pm 0.03$ & $13.29 \pm 0.10$ & $8.96 \pm 0.03$ & $11.65 \pm 0.08$ & $13.90 \pm 0.02$ & $12.53 \pm 0.02$ \\
Phosphate $(\mathrm{mg} / \mathrm{kg})$ & $3.96 \pm .01$ & $8.26 \pm .01$ & $3.36 \pm .0 .02$ & $4.36 \pm .0 .01$ & $5.18 \pm .0 .01$ & $4.63 \pm .0 .01$ \\
Ammonium nitrogen & $1.75 \pm 0.01$ & $2.17 \pm 0.01$ & $2.56 \pm 0.01$ & $1.88 \pm 0.01$ & $2.22 \pm 0.01$ & $2.02 \pm 0.00$ \\
(mg/kg) & $2.62 \pm 0.02$ & $5.46 \pm 0.01$ & $3.20 \pm 0.04$ & $4.92 \pm 0.01$ & $5.44 \pm 0.04$ & $4.52 \pm 0.00$ \\
Exc Base (meq/100g) & $1.18 \pm 0.01$ & $2.43 \pm 0.02$ & $1.48 \pm 0.01$ & $2.22 \pm 0.01$ & $2.46 \pm 0.03$ & $2.04 \pm 0.00$ \\
Exc Acid (meq/100g) & $1.33 \pm 0.01$ & $2.57 \pm 0.01$ & $3.68 \pm 0.01$ & $2.87 \pm 0.01$ & $3.36 \pm 0.02$ & $2.91 \pm 0.00$ \\
TOC (\%) & $0.17 \pm 0.01$ & $0.31 \pm 0.00$ & $0.44 \pm 0.01$ & $0.32 \pm 0.01$ & $0.42 \pm 0.01$ & $0.35 \pm 0.00$ \\
T.N. (\%) & $2.13 \pm 0.01$ & $4.11 \pm 0.01$ & $5.88 \pm 0.01$ & $4.60 \pm 0.01$ & $5.34 \pm 0.00$ & $4.67 \pm 0.01$ \\
Org Matter (\%) & $63.26 \pm 0.01$ & $71.98 \pm 0.00$ & $68.53 \pm 0.01$ & $77.94 \pm 0.00$ & $63.20 \pm 0.10$ & $64.14 \pm 0.07$ \\
Sand (\%) & & & &
\end{tabular}

$\mathrm{A}=$ soil from cow dung, $\mathrm{B}=$ poultry soil, $\mathrm{C}=$ soil from mechanic workshop, $\mathrm{D}=$ river soil, $\mathrm{E}=$ soil from farmland, $\mathrm{F}=$ garden soil

Table 2. Total heterotrophic bacteria count

\begin{tabular}{cl}
\hline Samples I.D. & THBC \\
\hline Soil A & $6.7 \times 10^{5}$ \\
Soil B & $5.5 \times 10^{5}$ \\
Soil C & $7.1 \times 10^{5}$ \\
Soil D & $4.3 \times 10^{5}$ \\
Soil E & $5.2 \times 10^{5}$ \\
Soil F & $7.9 \times 10^{5}$ \\
\hline
\end{tabular}

THBC- Total heterotrophic bacteria count. A= soil from cow dung, $\mathrm{B}=$ poultry soil, $\mathrm{C}=$ soil from mechanic workshop, $\mathrm{D}=$ river soil, $\mathrm{E}=$ soil from farmland, $\mathrm{F}=$ garden soil.

Table 3. Growth rate of Staphylococcus and Pseudomonas spp. before curing

\begin{tabular}{cccccc}
\hline & Day 0 & Day 1 & Day 2 & Day 3 & Day 4 \\
Staphylococcus A & $0.185^{\mathrm{c}} \pm 0.001$ & $0.420^{\mathrm{c}} \pm 0.010$ & $0.425^{\mathrm{g}} \pm 0.001$ & $0.443^{\mathrm{g}} \pm 0.001$ & $0.446^{\mathrm{h}} \pm 0.001$ \\
Staphylococcus B & $0.193^{\mathrm{d}} \pm 0.003$ & $0.272^{\mathrm{c}} \pm 0.001$ & $0.248^{\mathrm{c}} \pm 0.001$ & $0.284^{\mathrm{d}} \pm 0.000$ & $0.289^{\mathrm{c}} \pm 0.000$ \\
Staphylococcus D & $0.206^{\mathrm{f}} \pm 0.003$ & $0.370^{\mathrm{d}} \pm 0.001$ & $0.339^{\mathrm{f}} \pm 0.001$ & $0.382^{\mathrm{f}} \pm 0.001$ & $0.385^{\mathrm{g}} \pm 0.001$ \\
Staphylococcus F & $0.187^{\mathrm{c}} \pm 0.002$ & $0.185^{\mathrm{a}} \pm 0.005$ & $0.155^{\mathrm{a}} \pm 0.003$ & $0.188^{\mathrm{a}} \pm 0.000$ & $0.194^{\mathrm{b}} \pm 0.003$ \\
Pseudomonas B & $0.177^{\mathrm{b}} \pm 0.002$ & $0.407^{\mathrm{c}} \pm 0.001$ & $0.341^{\mathrm{f}} \pm 0.000$ & $0.322^{\mathrm{c}} \pm 0.000$ & $0.336^{\mathrm{f}} \pm 0.001$ \\
\hline Pseudomonas D & $0.201^{\mathrm{cf}} \pm 0.001$ & $0.182^{\mathrm{a}} \pm 0.001$ & $0.178^{\mathrm{b}} \pm 0.001$ & $0.187^{\mathrm{a}} \pm 0.001$ & $0.186^{\mathrm{a}} \pm 0.003$ \\
Pseudomonas $\mathrm{E}$ & $0.196^{\mathrm{de}} \pm 0.003$ & $0.225^{\mathrm{b}} \pm 0.005$ & $0.223^{\mathrm{d}} \pm 0.001$ & $0.257^{\mathrm{c}} \pm 0.001$ & $0.275^{\mathrm{d}} \pm 0.001$ \\
Pseudomonas $\mathrm{F}$ & $0.169^{\mathrm{a}} \pm 0.003$ & $0.219^{\mathrm{b}} \pm 0.001$ & $0.219^{\mathrm{c}} \pm 0.001$ & $0.233^{\mathrm{b}} \pm 0.001$ & $0.260^{\mathrm{c}} \pm 0.001$
\end{tabular}

Values are presented as means \pm standard error; Figures bearing similar superscripts within columns for same organism are not significantly different using Duncan's Multiple Range (DMR) test at 0.05 level of significance.

Legend: $\mathrm{A}=$ soil from cow dung, $\mathrm{B}=$ poultry soil, $\mathrm{D}=$ river soil, $\mathrm{E}=$ soil from farmland, $\mathrm{F}=$ garden soil.

Table 4. Growth rate of Staphylococcus and Pseudomonas spp. after curing

\begin{tabular}{cccccc}
\hline Isolates & Day 0 & Day 1 & Day 2 & Day 3 & Day 4 \\
\hline Staphylococcus A & $0.199^{\mathrm{bc}} \pm 0.001$ & $0.087^{\mathrm{d}} \pm 0.000$ & $0.125^{\mathrm{b}} \pm 0.001$ & $0.146^{\mathrm{b}} \pm 0.001$ & $0.273^{\mathrm{b}} \pm 0.001$ \\
Staphylococcus B & $0.205^{\mathrm{bc}} \pm 0.005$ & $0.089^{\mathrm{c}} \pm 0.001$ & $0.157^{\mathrm{c}} \pm 0.001$ & $0.215^{\mathrm{f}} \pm 0.005$ & $0.319^{\mathrm{f}} \pm 0.001$ \\
Staphylococcus D & $0.249^{\mathrm{c}} \pm 0.046$ & $0.128^{\mathrm{h}} \pm 0.001$ & $0.158^{\mathrm{c}} \pm 0.001$ & $0.186^{\mathrm{d}} \pm 0.001$ & $0.315^{\mathrm{c}} \pm 0.001$ \\
Staphylococcus F & $0.188^{\mathrm{b}} \pm 0.001$ & $0.079^{\mathrm{b}} \pm 0.000$ & $0.113^{\mathrm{a}} \pm 0.001$ & $0.127^{\mathrm{a}} \pm 0.001$ & $0.282^{\mathrm{c}} \pm 0.001$ \\
Pseudomonas B & $0.197^{\mathrm{bc}} \pm 0.001$ & $0.083^{\mathrm{c}} \pm 0.001$ & $0.134^{\mathrm{c}} \pm 0.001$ & $0.199^{\mathrm{c}} \pm 0.001$ & $0.347^{\mathrm{g}} \pm 0.001$ \\
Pseudomonas D & $0.128^{\mathrm{a}} \pm 0.001$ & $0.105^{\mathrm{g}} \pm 0.000$ & $0.181^{\mathrm{f}} \pm 0.001$ & $0.214^{\mathrm{f}} \pm 0.001$ & $0.378^{\mathrm{h}} \pm 0.001$ \\
Pseudomonas $\mathrm{E}$ & $0.176^{\mathrm{ab}} \pm 0.001$ & $0.067^{\mathrm{a}} \pm 0.001$ & $0.135^{\mathrm{c}} \pm 0.001$ & $0.173^{\mathrm{c}} \pm 0.001$ & $0.292^{\mathrm{d}} \pm 0.001$ \\
Pseudomonas $\mathrm{F}$ & $0.218^{\mathrm{bc}} \pm 0.001$ & $0.103^{\mathrm{f}} \pm 0.001$ & $0.151^{\mathrm{d}} \pm 0.001$ & $0.185^{\mathrm{d}} \pm 0.000$ & $0.258^{\mathrm{a}} \pm 0.001$ \\
\hline
\end{tabular}

Values are presented as means \pm standard error; Figures bearing similar superscripts within columns for same organism isolated from different soil samples are not significantly different using Duncan's Multiple Range (DMR) test at 0.05 level of significance.

Legend: $\mathrm{A}=$ soil from cow dung, $\mathrm{B}=$ poultry soil, $\mathrm{D}=$ =river soil, $\mathrm{E}=$ soil from farmland, $\mathrm{F}=$ garden soil. 
Table 5. Comparison of growth rate of Staphylococcus and Pseudomonas spp. isolated from different soil samples before and after curing

\begin{tabular}{|c|c|c|c|c|c|c|}
\hline Treatment & Time & Mean & Std. Deviation & t-value & P-value & Inference \\
\hline \multirow{2}{*}{ Staphylococcus A } & Before & 0.3836 & 0.000 & & & \\
\hline & After & 0.1657 & 0.0679 & 5.107 & 0.001 & Significant difference \\
\hline \multirow{2}{*}{ Staphylococcus B } & Before & 0.2570 & 0.0372 & & & \\
\hline & After & 0.1967 & 0.0797 & 2.349 & 0.043 & Significant difference \\
\hline \multirow{2}{*}{ Staphylococcus D } & Before & 0.3359 & 0.0709 & & & \\
\hline & After & 0.2068 & 0.0739 & 3.699 & 0.005 & Significant difference \\
\hline \multirow{2}{*}{ Staphylococcus F } & Before & 0.1815 & 0.0149 & & & \\
\hline & After & 0.1574 & 0.0752 & 1.098 & 0.301 & No significant difference \\
\hline \multirow{2}{*}{ Pseudomonas B } & Before & 0.3165 & 0.0798 & & & \\
\hline & After & 0.1915 & 0.0935 & 2.860 & 0.019 & Significant difference \\
\hline \multirow{2}{*}{ Pseudomonas D } & Before & 0.1864 & 0.0083 & & & \\
\hline & After & 0.2009 & 0.1015 & -0.446 & 0.666 & No significant difference \\
\hline \multirow{2}{*}{ Pseudomonas $\mathrm{E}$} & Before & 0.2350 & 0.0296 & & & \\
\hline & After & 0.1682 & 0.0771 & 3.310 & 0.009 & Significant difference \\
\hline \multirow{2}{*}{ Pseudomonas $\mathrm{F}$} & Before & 0.2197 & 0.0314 & & & \\
\hline & After & 0.1826 & 0.0563 & 1.973 & 0.080 & No significant difference \\
\hline
\end{tabular}

Legend: P-value $<0.05=$ significant, $\mathrm{P}$-value $>0.05$ = not significant

\section{Discussion}

In this study, the physiochemical analysis of the test soil samples was carried out. The results obtained from the physicochemical analysis indicated that the soil samples varied in their physicochemical properties. The variation can be attributed to different natural and anthropogenic activities taking place in the different environments. The various soil samples gave slightly acidic $\mathrm{pH}$ values in all the soil samples analyzed (Table 1). The acidic nature of the soil could be attributed to interaction of biotic and abiotic factors in the different soil environment.

The heterotrophic bacteria count in the various soil samples (Table 2) showed a highest value $\left(7.9 \times 10^{5}\right)$ recorded for soil sample $\mathrm{F}$ (garden soil) compared to the other soils. Soil components influence the distribution and diversity of microorganisms in a particular soil (Kumar, 2011). The higher heterotrophic bacteria count recorded in soil sample $F$ could be attributed to the physicochemical properties of the soil (Table 1). The lower heterotrophic bacteria count recorded in soil sample D (river soil) could also be attributed to the physicochemical properties of the soil.

In this study, the isolated bacteria were Escherichia coli, Streptococcus sp., Pseudomonas sp., Staphylococcus sp. and Bacillus sp. The growth rates of Pseudomonas and Staphylococcus spp. were investigated.

In view of the growth rate of Staphylococcus and Pseudomonas spp. before curing (Table 3), there were significant differences recorded in the various days observed $(0-4)$ in the growth rate of Staphylococcus sp. isolated from the different soil samples. This suggested that the soil environment from which the organisms were isolated has a potential of affecting the growth rate of the organisms, which may in the long run affect its virulence. This is because the ability to grow and proliferate fast in the host by a pathogen can also be attributed to its virulence (Agrios, 2005). The differences observed in growth rate may suggest that the soil environment may have altered or modify the nature of the pathogen. However, this should be further investigated at the molecular level. Soil-inhabiting bacterial pathogens are exposed to various physical, biological and chemical factors in the environment and these factors tend to affect the growth and proliferation of these pathogens. The results in Table 3 also indicated a negligible difference in the growth rate of test bacteria after day o. This can be attributed to the fast growth rate of bacteria. They tend to complete their life cycles within 24-48 hours and this ability is controlled by their genes. Adeyemo and Onilude (2015) have reported that plasmid curing shows significant negative impact on the growth rate of Lactobacillus plantarum. There was no significant difference at day 1 in the growth rate of Pseudomonas sp. isolated from soil sample E and F, but there were significant differences in the other days observed. The differences in growth rate could be due to the different nature of the organism and interaction of biotic and abiotic factors in the soil where the organisms were isolated that must have altered the nature of the organism (Kumar, 2011).

The growth rate of Staphylococcus and Pseudomonas spp. isolated from different soil samples after curing (Table 4) showed that there was no significant difference between the growth rate of Staphylococcus sp. isolated from sample A and $\mathrm{B}$ after curing at day $0\left(0.199^{\mathrm{bc}} \pm 0.001\right.$ and $0.205^{\mathrm{bc}} \pm 0.005$ respectively). However, post hoc analysis using the Duncan multiple range test indicated significant differences in the growth rate of Staphylococcus sp. in the other days observed. This suggested that the soil environment from which the organisms were isolated has a potential of affecting the growth rate of the organisms, which may inadvertently affect its virulence. The difference in growth could be as a result of alteration in the nature of the pathogen by variation in soil environment. However, this should be further investigated at the molecular level. Significant differences were observed in the growth rate of Pseudomonas sp. isolated from sample $\mathrm{F}$ and $\mathrm{B}$ at day 0 after curing $\left(0.218^{\mathrm{bc}} \pm 0.001\right.$ and $0.197^{\mathrm{bc}} \pm 0.001$ respectively). The differences in growth rate suggested a difference in the test organism. The growth rate of Staphylococcus and 
406

Pseudomonas spp. before and after curing showed that there were significant differences $(\mathrm{p}<0.05)$ in the growth rate of Staphylococcus sp. isolated from sample A, B and D, before and after curing, while there was no significant difference ( $p>0.05)$ in the growth rate of Staphylococcus sp. isolated from sample F before and after curing (Table 5). Significant differences $(\mathrm{p}<0.05)$ were observed in the growth rate of Pseudomonas sp. isolated from sample B and E before and after curing, but there were no significant differences in the growth rate of Pseudomonas sp. isolated from sample $\mathrm{D}$ and $\mathrm{F}$ before and after curing. The differences observed in the growth rate before and after curing suggested that the plasmid DNA plays an important role in the growth of the test organisms where differences were observed. This observation agrees with the work of Adeyemo and Onilude

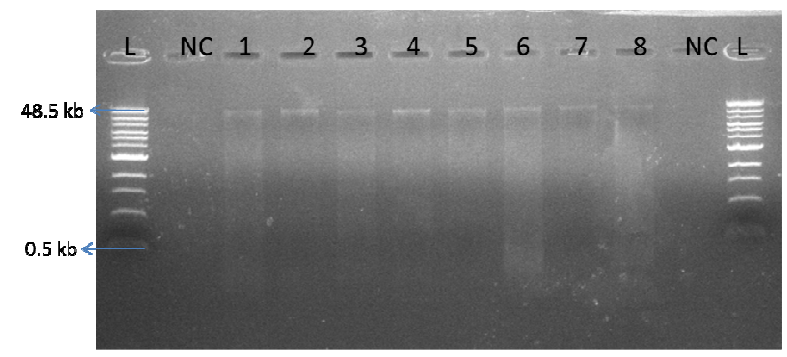

Fig. 1. Plasmid profile of Pseudomonas sp. and Staphylococcus sp. isolated from soil samples, analyzed with $0.8 \%$ agarose gel electrophoresis stained with ethidium bromide

Key: $\mathrm{L}$ is $0.5 \mathrm{~kb}-48.5 \mathrm{~kb}$ ladder (molecular marker). Samples 1 , $2,3,4,5,6,7$ and 8 are positive for plasmid genes with band at $30 \mathrm{~kb} . \mathrm{NC}$ is a no plasmid DNA template control.

1. = Pseudomonas $\mathrm{sp}$. from poultry soil

2. $=$ Pseudomonas $\mathrm{sp}$. from river soil

3. = Pseudomonas sp. from farm land soil

4. = Pseudomonas sp. from garden soil

5. = Staphylococcus sp. from cow dung soil

6. = Staphylococcus sp. from poultry soil

7. = Staphylococcus sp. from river soil

8. = Staphylococcus sp. from garden soil

\section{Conclusions}

The results from this study suggested that the soil environments from which the various bacteria were obtained has effect on the genetics of the bacterial isolates and the physicochemical analysis indicated that the soil samples varied in their physicochemical properties. Further studies should be carried out to perform a molecular profiling of the various isolates to determine species specificity and also test for their virulence in order to recommend possible ways of preventing diseases caused by these pathogens.

\section{Conflict of Interest}

The authors declare that there are no conflicts of interest related to this article.
(2015) who have reported that plasmid curing shows significant negative impact on the growth rate of Lactobacillus plantarum. The presence of plasmid in bacteria confers special ability such as tolerance to antibiotics, increased virulence and heavy metal tolerance (Durve et al., 2013; Akinjogunla and Enabulele, 2010). Samples 1, 2, 3, 4, 5, 6, 7 and 8 representing Pseudomonas sp. from poultry soil, river soil, farmland soil, garden soil, cow dung soil and Staphylococcus sp. from cow dung soil, poultry soil, river soil garden soil respectively were positive for plasmid genes before curing (Fig. 1), but they became negative for plasmid genes after curing (Fig. 2) This showed that the plasmids were completely removed during the curing process.

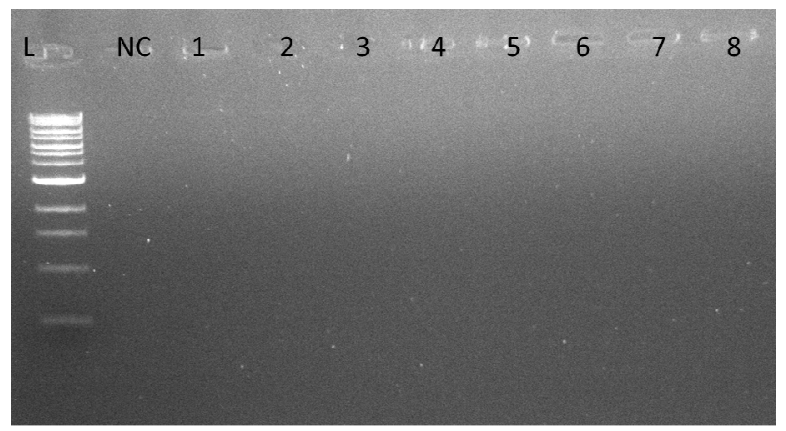

Fig. 2. Plasmid profile of cured Pseudomonas sp. and Staphylococcus sp. isolated from soil samples, analyzed with $0.8 \%$ agarose gel electrophoresis stained with ethidium bromide

Key: $\mathrm{L}$ is $0.5 \mathrm{~kb}-48.5 \mathrm{~kb}$ DNA ladder (molecular marker). Samples 1, 2, 3, 4, 5, 6, 7 and 8 are negative for plasmid genes. NC is a no plasmid DNA template control.
1. = Pseudomonas sp. from poultry soil
2. = Pseudomonas sp. from river soil
3. = Pseudomonas sp. from farm land soil
4. = Pseudomonas sp. from garden soil
5. = Staphylococcus sp. from cow dung soil
6. $=$ Staphylococcus sp. from poultry soil
7. = Staphylococcus sp. from river soil
8. = Staphylococcus sp. from garden soil

\section{References}

Adeyemo SM, Onilude AA (2015). Plasmid curing and its effect on the growth rate and physiological characteristics of Lactobacillus plantarum isolated form fermented cereals. Journal of Microbiology Research 5(1):11-22.

Agrios GN (2005). Plant pathology. Fifth Edition. Elsevier Academic Press, London.

Bennett MR, Pang WL, OstroffNA, Baumgartner BL, Nayak S, Tsimring LS, Hasty J (2008). Metabolic gene regulation in a dynamically changing environment. Nature 454(7208):1119-1122. 
Bremner DC, Mulvaney JM (1982). Total nitrogen. In: Page AL, Miller RH, Keaney DR(Eds). Methods of Soil Analysis. American Society of Agronomist. No9part2.

Carattoli A (2011). Plasmids in Gram negatives: molecular typing of resistance plasmids. International Journal of Medical Microbiology 301(8):654-658.

Ehiaghe FA, Ehiaghe IJ, Agbonlahor DE, Oviasogie FE, Etikerentse SMO, Nwobu RAU, ... Enwa FO (2013). Plasmid profiling and curing analysis of fluoroquinolone multidrug resistant $P$ seudomonas aeruginosa in Benin City, Nigeria. Open Journal of Medical Microbiology 3(3):201-205.

Kalra YP, Maynard DG (1991). Methods manual for forest soil and plant analysis. Edmonton: Forestry Canada, Northwest region, Northern Forestry Center.Information Report NOR-X-319.

Kumar S (2011). Effects of soil physicochemical properties on Chlorpyrifos tolerant bacteria from cultivated soil. Electronic Journal of Environmental Sciences 4:17-23.
407

Onyeonwu RO (2000). Manual for waste/wastewater, soil/sediment, plant and fish analysis. McGill, Environmental Research Laboratory Manual, Benin City.

Ranjbar M, Karamian R, Tolui, Z, Amirabadizadeh H (2007). Onobrychis assadii (Fabaceae), a new species from Iran. Annales Botanici Fennici 44:481-484.

Sambrook JF, Russell DW (2001). Molecular cloning: a laboratory manual. Third edition. Cold Spring Harboar Laboratory Press.

Sengupta M, Austin S (2011). Prevalence and significance of plasmid maintenance functions in the virulence plasmids of pathogenic bacteria. Infection and Immunity 79(7):2502-2509.

Weaver RF (2012). Molecular biology. Fifth edition. McGraw-Hill Companies, New York, United State of America.

Zhang H, Hao Y, Zhang D, Luo Y (2011). Characterization of the cryptic plasmid pTXW fromLactobacillusparacasei TXW. Plasmid 65(1):1-7. 